\title{
Beobachtung der Sonnenfinsterniss 1882 Mai 16 auf der Sternwarte zu Bonn.
}

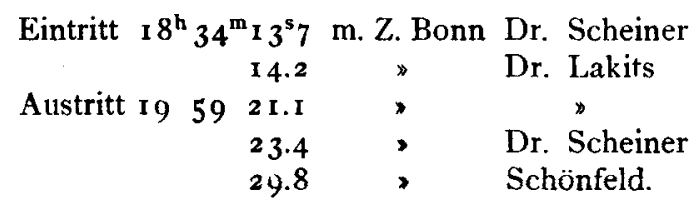

Die Beobachtungen sind vielleicht zweier Verbesserungen bedürftig. Die ursprüngliche Notirung des Herrn Dr. Lakits giebt für den Eintritt $34^{\mathrm{m}} 44^{\mathrm{s}} 2$, derselbe glaubt aber sicher, dass er sich nur um $30^{\mathrm{s}}$ verzählt habe. Ich selbst wurde bei dem Controliren der Uhr nach der Beobachtung zweifelhaft, ob nicht die notirte Zeitsecunde um + ro zu corrigiren sei, weil mir das Zeitintervall zwischen Austritt des Mondes und Contıoliren der Uhr viel kleiner gewesen zu sein schien, als der Notirung entsprach. Ich halte aber doch jetzt diesen Fehler für unwahrscheinlich und bin bei der ursprünglichen Notirung geblieben.

Die Fernröhre waren für Scheiner das $4 \frac{1}{2}$ füssige (Benzenberg'sche) Fernrohr, Vergrösserung 96. Dr. Lakits und ich haben mit Frauenhofer'schen 30 zölligen Fernröhren und 60 maliger Vergrösserung beobachtet. Die im Ganzen sehr wechselnde Iuft fand ich gerade zur Zeit des Endes der Finsterniss sehr ruhig, so dass ich den flachen Einschnitt des Mondes mit Ruhe bis zu seinem Verschwinden verfolgen konnte.

Bonn 1882 Oct. I 3 .

\section{E. Schönfeld.}

\section{On the orbit of the Great Comet.}

\section{Published with the permission of Prof. E. C. Pickering.}

I herewith communicate parabolic and elliptic elements of the great comet, obtained by Mr. O.C. Wendell and myself from the following normal places:

\begin{tabular}{|c|c|c|c|c|c|c|}
\hline \multirow{2}{*}{\multicolumn{2}{|c|}{$\begin{array}{l}\text { Greenwich M.T. } \\
\text { Sept. } 20.00000\end{array}$}} & $\alpha \mathbf{I}$ & 2.0 & \multicolumn{3}{|c|}{$\delta_{\text {I } 882.0}$} \\
\hline & & I I $^{\mathbf{h}} \mathrm{I}_{5}$ & $17^{5}: 47$ & - & & $35: 6$ \\
\hline & & 1033 & $5^{6.87}$ & - & 55 & 20.8 \\
\hline & 19.92081 & 1013 & 12.48 & -I 5 & 10 & $39 \cdot 7$ \\
\hline
\end{tabular}

The $1^{\text {st }}$ normal was based on seven observations from Sept. I 8-Sept. 2 I, at Dun Echt, Coimbra and Washington, giving two of them (Washington Sept. 20 and 21.) quadruple weight; the $2^{\text {d }}$ from ten observations Sept. 30-Oct. 9, at Glasgow, Missouri, Albany, and at this observatory; and the $3^{\mathrm{d}}$ from three observations at Albany, and this observatory, on the $19^{\text {th }}$ October.

It was found that the normals could not be satisfied with a parabola. The derived elements:

$$
\left.\begin{array}{rl}
T & =\text { Sept. } 17.22013 \text { Gr. m. } T . \\
\omega & =69^{\circ} 28^{\prime} 4^{\prime} \cdot 4 \\
\delta & =3455340.4 \\
i & =1415515.0
\end{array}\right\} \text { m. Aeq. } 1882.0
$$

leaving outstanding the residuals $(\mathrm{C}-\mathrm{O})$

$$
\begin{aligned}
\Delta \lambda \cos \beta & =+18.8 \\
\Delta \beta & =+8.9
\end{aligned}
$$

An elliptic orbit computed from the same data gave the elements:

$$
\begin{aligned}
& T=\text { Sept. I } 7.2304 \text { Gr. M. T. } \\
& \infty=69^{\circ} 22^{\prime} 7.2 \\
& \Omega=345 \text { 50 } 34.0 \\
& i=14154 \quad 56.2 \\
& \log q=7.8835^{6} 3^{6} \\
& e=0.9999700
\end{aligned}
$$

I believe the deviation from a parabola thus indicated, to be real, although the corresponding period is very long.

It should be remarked that the $8 \frac{1}{2}$ year ellipse published on Oct. 5, was vitiated by an error in the position of the $23^{\mathrm{d}}$ of September, which, on account of the scantiness of the available data could not be detected at that time.

I append values of the coordinates for the equator by both of the above sets of elements (equinox 1882.0)

$$
\begin{aligned}
& \text { P a } \mathbf{r} \text { a } \\
& x=r[9.9950379] \sin \left(170^{\circ} 40^{\prime} 5^{\prime \prime} 7+v\right) \\
& y=r[9.9876182] \sin (262 \quad 46 \quad 43.7+v) \\
& z=r[9.4460963] \sin \left(\begin{array}{lll}
49 & 9 & 30.9+v)
\end{array}\right. \\
& \text { E } 11 \text { i p s e. } \\
& x=r[9.9950007] \sin (\text { I } 7035 \quad 53.8+v) \\
& y=r[9.9876224] \sin (2624259.4+v) \\
& z=r\left[9.44^{6} 5_{116}\right] \sin \left(\begin{array}{lll}
48 & 59 & 30.2+v)
\end{array}\right.
\end{aligned}
$$

The orbits here given represent the earliest ante-perihelion position known to us at this writing, - that of Sept. 8, at the Cape of Good Hope, as follows:

$$
\begin{aligned}
& \text { Parabola . . . . }+2^{\mathrm{s}} \cdot 5+96^{\prime \prime} \\
& \text { Ellipse .....-2.5 }+7^{6}
\end{aligned}
$$

These differences seem to indicate that the disturbance suffered by the comet in passing through the coronal region could not have been great. The same inference may be drawn from the transit-ingress observed at the Cape of Good Hope. According to the above parabola the comet at the instant named would have passed upon the sun's limb, and by the ellipse it had not quite reached it, the difference being about $I: 5$ of arc. A change of 5 or 6 minutes of time in the perihelion passage would account for the difference observed, and this quantity is certainly within the limits of uncertainty of the determination.

Harvard College Observatory 1882 Oct. 28 . S. C. Chandler jr. 